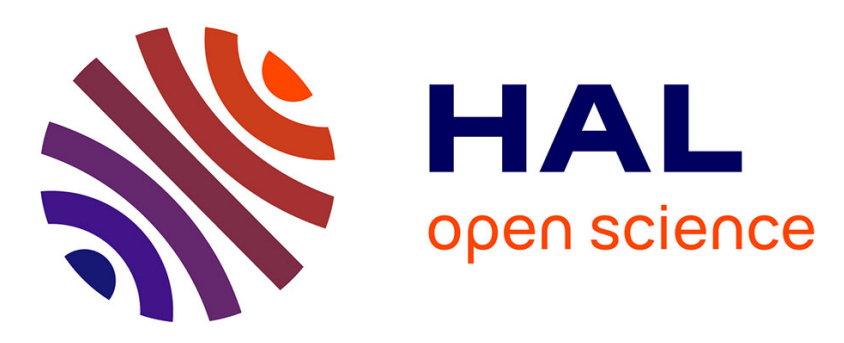

\title{
Forms of work organization and associations with shoulder disorders: Results from a French working population
}

Julie Bodin, Ronan Garlantézec, Nathalie Costet, Alexis Descatha, Natacha Fouquet, Sandrine Caroly, Yves Roquelaure

\section{To cite this version:}

Julie Bodin, Ronan Garlantézec, Nathalie Costet, Alexis Descatha, Natacha Fouquet, et al.. Forms of work organization and associations with shoulder disorders: Results from a French working population. Applied Ergonomics, 2017, 59, pp.1-10. 10.1016/j.apergo.2016.07.019 . hal-01389315

\section{HAL Id: hal-01389315 https://hal.science/hal-01389315}

Submitted on 19 Mar 2020

HAL is a multi-disciplinary open access archive for the deposit and dissemination of scientific research documents, whether they are published or not. The documents may come from teaching and research institutions in France or abroad, or from public or private research centers.
L'archive ouverte pluridisciplinaire HAL, est destinée au dépôt et à la diffusion de documents scientifiques de niveau recherche, publiés ou non, émanant des établissements d'enseignement et de recherche français ou étrangers, des laboratoires publics ou privés. 
Title: Forms of work organization and associations with shoulder disorders: results from a French working population

\section{Authors:}

Julie Bodin ${ }^{\mathrm{a}}$, Ronan Garlantézec ${ }^{\mathrm{b}, \mathrm{c}}$, Nathalie $\operatorname{Costet}^{\mathrm{b}}$, Alexis Descatha ${ }^{\mathrm{d}, \mathrm{e}}$, Natacha Fouquet ${ }^{\mathrm{a}, \mathrm{f}}$, Sandrine Caroly ${ }^{\mathrm{g}}$, Yves Roquelaure ${ }^{\mathrm{a}, \mathrm{h}}$

${ }^{\text {a}}$ University of Angers, Laboratory of Ergonomics and Epidemiology in Occupational Health (LEEST), Angers, France

bIRSET INSERM U1085, University Rennes I, Rennes, France

${ }^{\mathrm{c}}$ EHESP, School of Public Heatlh, Rennes, France

'INSERM, UMS 011, 'Population-Based Epidemiological Cohorts' Research Unit, Villejuif, France

${ }^{\mathrm{e} U n i v}$ Versailles St-Quentin, Versailles, France

${ }^{\mathrm{f}}$ Santé publique France, French national public health agency, Direction of Occupational

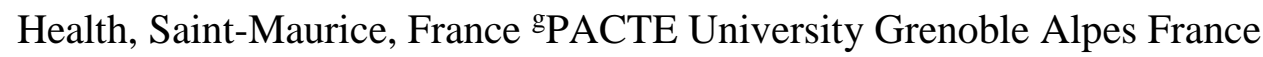

${ }^{\mathrm{h}}$ University Hospital,CHU Angers, Angers, France

Correspondence to: Julie Bodin, LEEST - UA Santé publique France - EA 4336, Faculté de Médecine, Rue Haute de Reculée, 49045 ANGERS Cedex 01, France.

E-mail: julie.bodin@univ-angers.fr

Tél: + 33241735911 


\section{ABSTRACT}

The aim of this study was to identify forms of work organization in a French region and to study associations with the occurrence of symptomatic and clinically diagnosed shoulder disorders in workers. Workers were randomly included in this cross-sectional study from 2002 to 2005. Sixteen organizational variables were assessed by a self-administered questionnaire: i.e. shift work, job rotation, repetitiveness of tasks, paced work/automatic rate, work pace dependent on quantified targets, permanent controls or surveillance, colleagues' work and customer demand, and eight variables measuring decision latitude. Five forms of work organization were identified using hierarchical cluster analysis (HCA) of variables and HCA of workers: low decision latitude with pace constraints, medium decision latitude with pace constraints, low decision latitude with low pace constraints, high decision latitude with pace constraints and high decision latitude with low pace constraints. There were significant associations between forms of work organization and symptomatic and clinically-diagnosed shoulder disorders.

KEY TERMS: Work organization; Classification; Shoulder disorders 


\section{Introduction}

Several models of work systems coexist in industrial and service sectors, such as the Japanese lean production (or Toyotism), the American human resource model, the Swedish sociotechnical systems, the Italian flexible specialization and the German diversified quality production (Coutrot, 1998; Drago, 1995). They differ according to the target market (mass consumption, niche market, upscale, etc.), the work organization (defined by Hagberg et al. as the more "objective aspects of how the work is organized, supervised and carried out" (Hagberg et al., 1995), such as for example the application of an ISO quality standard, teamwork, job rotation, autonomy), human resource management (modality of payment, training, etc.) and professional relations (trade union, participation, etc.). For example, lean production aims to eliminate waste and is based on several principles including Total Quality Management (TQM) and just-in-time (JIT) (Brännmark and Håkansson, 2012; Coutrot, 1998; Koukoulaki, 2014; Landsbergis et al., 1999). However, all production systems tend to offer more flexibility and reactivity to the market and customer demands and can, according to some studies, lead to work intensification (Westgaard and Winkel, 2011; European Foundation for the Improvement of Living and Working Conditions, 2003).

Musculoskeletal disorders (MSDs) are the most commonly occurring occupational diseases in France, representing 87\% of occupational diseases (45079 cases) in 2014 (Assurance maladie - Risques professionnels, 2015). Shoulder disorders represented 29\% of all MSDs. The shoulder is the second most frequent location of MSDs, after the wrist/hand locations (40\%) but it causes longer periods of absence from work, loss of productivity and higher economic costs for employers (Hopman et al., 2013; Kuijpers et al., 2004; van der Windt et al., 2000; van Rijn et al., 2010).

Most studies of the risk factors for shoulder disorders have focused on direct biomechanical risk factors (e.g. postures, vibration) determining the mechanical load applied to soft tissues. 
Some studies have taken psychosocial risk factors into consideration, classically defined by Hagberg et al. as "the subjective perceptions of work organizational factors" and how they are perceived by workers (Hagberg et al., 1995). Most epidemiological studies in the literature refer to the models of stress at work such as the Job Demand Control (JDC) model and the EffortReward Imbalance (ERI) model. However, few have studied the influence of factors related to the work organization. Factors related to the work organization correspond to many dimensions (e.g. processes, rotation, links with hierarchy, training) and can be evaluated by consulting the company's internal documents and by interview or self-administered questionnaire for the management (Amossé and Coutrot, 2008; Amossé et al., 2014; Härenstam et al., 2004) or workers (Carayon, 1994; Engkvist et al., 2001; European Foundation for the Improvement of Living and Working Conditions, 2012). Hagberg et al. indicated that "organizational and psychosocial factors may be the same (e.g. career structuring in an organization), but psychosocial factors carry 'emotional' value for the worker".

Several conceptual models linking work organization and MSDs have been developed (Bellemare et al., 2002; Carayon et al., 1999; Karsh, 2006; Sauter and Swanson, 1996). Our research group has proposed a multidimensional conceptual model of MSDs for the purpose of epidemiological studies (Roquelaure, 2016). According to these models, the work organization is a major determinant of biomechanical and psychosocial constraints. For example, the temporal (cycle time, work/rest period, etc.) and physical (workstation dimensions, loads and force level required, etc.) characteristics of the work situation determine exposure to biomechanical factors (Askenazy et al., 2002; Askenazy and Caroli, 2010; Brännmark and Håkansson, 2012; Koukoulaki, 2014; Landsbergis et al., 1999; St-Vincent et al., 2014; Westgaard and Winkel, 2011). Similarly, work organization and management practices influence work-related psychosocial factors by determining the human resources allocated to the production activity, and also the quality of work relationships and social support. Factors 
related to work organization therefore determine the main risk factors for MSDs (i.e. biomechanical and psychosocial factors) and can be considered as indirect risk factors for MSDs. For example, the pace of work production determines the repetitiveness of arm movement, and consequently it is important to act on the pace of work in order to reduce the repetitiveness and thus reduce the risk of MSDs. Work organization and management practices influence not only work-related constraints, but also individual resources to interact with their work environment and to cope with these constraints (Lazarus, 1991; St-Vincent et al., 2014). Indeed, as suggested by Sauter \& Swanson (Sauter and Swanson, 1996), the development of musculoskeletal symptoms is mediated not only by physiological strain of the soft tissues, but also by a complex of cognitive processes involving the detection and labelling/attribution of somatic information as symptoms of MSDs. The latter psychological mechanisms have a major role in the appearance and prognosis of MSDs (Bongers et al., 2006), but are difficult to evaluate by epidemiological studies.

There is conflicting evidence regarding the relationships between organizational practices (e.g. application of an ISO quality standard, teamwork, quality circles, job rotation) and the risk of MSDs (Askenazy and Caroli, 2010; Askenazy et al., 2002; Brännmark and Håkansson, 2012; Ferreira Júnior et al., 1997; Landsbergis et al., 1999; Marklund et al., 2008; Westgaard and Winkel, 2011). Using the data of the epidemiologic MSD surveillance system in the Pays de la Loire region (Loire Valley district, west-central France) (Ha et al., 2009), we studied the role of biomechanical, psychological and organizational factors in MSDs. We showed no or moderate associations between organizational (e.g. work pace dependent on automatic rate, work with temporary workers) and psychological factors (e.g. high psychosocial demand, low decision authority, low social support) and shoulder disorders, biomechanical factors being predominant (Bodin et al., 2012a, 2012b, 2012c; Roquelaure et al., 2011). 
Nevertheless work organization cannot be summarized in a single variable which could wrongly express several embedded dimensions, such as teamwork, job rotation and autonomy (Caroly et al., 2010). A few studies have identified forms of work organization based on several organizational and psychosocial variables using classification methods (Amossé and Coutrot, 2008; Amossé et al., 2014; Carayon, 1994; Daubas-Letourneux and Thébaud-Mony, 2002; Engkvist et al., 2001; Härenstam et al., 2004; Leijon et al., 2006; Lorenz and Valeyre, 2005; Valeyre, 2006; Valeyre et al., 2009), but none has focused on the risk of shoulder pain.

We hypothesize that some forms of work organization with high organizational constraints carry more risk for shoulder disorders than others. Identifying such forms of work organization more accurately could be useful to improve understanding of the relationships between work organization and MSDs, in particular shoulder disorders. From a practical point of view, organizational factors might be levers for action for ergonomists to reduce exposure to biomechanical and psychosocial factors and thus reduce the prevalence of shoulder disorders. This could help ergonomists to implement preventive actions for workers exposed to these deleterious forms of work organization (Roquelaure, 2015).

The aim of the present epidemiological study was first to identify forms of work organization characterized by patterns of organizational and psychosocial variables in a sample of French workers, and secondly to compare symptomatic and clinically-diagnosed shoulder disorders according to these different forms of work organization.

\section{Methods}

\subsection{Participants}

This cross-sectional study was based on a large sample of workers of the Loire Valley region (West Central France, French Public Health Agency). All salaried workers in France, including temporary and part-time workers, undergo a mandatory health examination by an occupational physician (OP) in charge of the medical surveillance of a group of companies. All OPs 
practicing in this region between 2002 and 2005 were invited to participate, and 83 of them (18\%) volunteered to take part in the study. Workers were selected at random, following a twostage sampling procedure: first, 15 to 30 half-days of scheduled examinations for each OP were chosen for sampling by the investigators. Next, each OP was asked to randomly select one from the scheduled ten workers on the selected half-days of worker examinations (Roquelaure et al., 2006). The selected workers were then examined by the OPs. A total of 3710 workers were included (2.0\% of workers surveyed by the $83 \mathrm{OPs})$. Comparison of their socio-economic status with the French census (1999) (http://www.insee.fr) showed no major differences for either gender. Overall, the distribution of occupations was close to that of the regional workforce, except for the few occupations not surveyed by OPs (e.g., shopkeepers and independent workers) (Roquelaure et al., 2006).

Craftsmen, salesmen and managers who are mainly self-employed workers can decide for themselves about their work organization, and thus they were not comparable to salaried workers. Moreover, there were very few $(n=16)$ and thus were not comparable to craftsmen, salesmen and managers of the region. Analysis on this group was not possible and we therefore decided to exclude these occupations. The same was true for agriculture workers $(n=71)$. Moreover, workers with values missing for at least one of the organizational variables studied were excluded ( $\mathrm{n}=382$ ). The final sample size was 3241 (Figure 1).

A self-administered questionnaire was completed by workers before the medical examination performed by the OP. The work constraints and work organization factors evaluated in this study are thus the workers' perceptions.

\subsection{Variables}

\subsubsection{Organizational variables}

Sixteen organizational variables were studied according to the literature (Daubas-Letourneux and Thébaud-Mony, 2002; Lorenz and Valeyre, 2005; Valeyre, 2006; Valeyre et al., 2009). The 
questions were derived from large French studies, e.g. the SUMER survey (medical surveillance of occupational risks) of the DARES (Directorate for Research, Studies, and Statistics):

- Shift work: "Do you work shifts $(2 \times 8,3 \times 8$ or more)?" The question had three response options: no; yes in fixed teams; yes in alternating teams. In fixed teams, workers still work in the same time slot. In alternating teams, schedules change according to the time period.

- Job/task rotation: "Do you occupy different jobs or positions (polyvalence) at work?" The question was graded according to five response options: almost never/never; one to 3 days per month; one day per week; 2 to 4 days per week; daily. The question was analyzed in two modalities: less than one day per week and one day per week or more.

- Repetitiveness of tasks: "Does your job usually require you to repeatedly perform the same actions more than about 2 to 4 times per minute?" Response categories were presented on a 4-level Likert-type scale, as follows: never; less than 2 hours/day; 2 to 4 hours/day; more than 4 hours/day. The question was analyzed in three modalities: never or less than 2 hours/day; 2 to 4 hours/day; more than 4 hours/day.

- Five binary variables (yes/no) measuring the work pace: "During a typical day, is your work pace imposed on you by...?"

- Paced work/automatic rate

○ Colleagues' work

○ Quantified targets

○ Permanent controls or surveillance

- Customer demand

- Eight variables measuring decision latitude were assessed from the Job Content Questionnaire (JCQ) (Karasek et al., 1998; Niedhammer et al., 2006): three referring to 
the decision authority (allows own decisions, little decision freedom and a lot of say) and five referring to the skill discretion (learning new things, requires creativity, high skill level, variety, develop own abilities). Answers were graded according to the following 4-level Likert-type scale: totally disagree, disagree, agree, and totally agree, and for the analyses, the "totally disagree" and "disagree" categories were grouped due to the small number of subjects who responded to "totally disagree". The variable "little decision freedom" was formulated in a negative way, so it was analyzed in three modalities: totally disagree, disagree and agree/totally agree. Decision latitude refers to the leeway which the worker has to influence decisions in his work and to use or develop skills. The "repetitive work" variable was not studied because it was too close to the variable "repetitiveness of tasks". The decision latitude dimension of the JCQ was taken into consideration because it was close to the questions used in previous studies (Daubas-Letourneux and Thébaud-Mony, 2002; Lorenz and Valeyre, 2005; Valeyre, 2006; Valeyre et al., 2009) identifying forms of work organization (i.e. autonomy and cognitive content of work) in contrast to the two other dimensions of JCQ (i.e. psychosocial job demand and social support).

\subsubsection{Shoulder disorders}

The presence of non-specific shoulder pain during the preceding 12 months and the preceding seven days was assessed in the questionnaire by means of a modified version of the standardized Nordic-style questionnaire (Hagberg et al., 1995; Kuorinka et al., 1987). A mannequin was used to denote the different anatomical regions. The duration of pain during the preceding 12 months was noted ( $<24$ hours, 1-7 days, 8-30 days, $>30$ days and permanently). If pain of any duration had occurred during the preceding 12 months, a physical examination was performed by the OP using a standardized clinical procedure based on the criteria document for the evaluation of 
work-related MSDs (Sluiter et al., 2001). Rotator cuff syndrome was diagnosed if (i) there was intermittent pain in the shoulder region (without paresthesia) currently or for at least 4 days during the preceding seven days, worsened by active elevation of the upper arm as in scratching the upper back; and (ii) at least one of the following shoulder tests was positive: resisted shoulder abduction, external or internal rotation; resisted elbow flexion; painful arc on active upper arm test (abduction-elevation).

\subsubsection{Coding of occupations and economic sectors}

Occupations were assessed in the self-administered questionnaire, and occupation categories were coded using the French classification of occupations (Nomenclature des Professions et Catégories Socioprofessionnelles [PCS]) published by the French National Institute of Statistics and Economic Studies (INSEE) in 1994. Economic sectors were identified by the OP and coded using the French version of the statistical classification of economic activities in the European Community (Nomenclature d'Activités Françaises [NAF]) published by INSEE in 2000.

\subsection{Statistical analysis}

No assumption was made in this study about possible differences in organizational forms according to gender (Amossé and Coutrot, 2008; Amossé et al., 2014; Carayon, 1994; Härenstam et al., 2004; Leijon et al., 2006; Lorenz and Valeyre, 2005; Valeyre, 2006; Valeyre et al., 2009). In the initial step, the analyses were stratified according to occupational category (using the French classification of occupations, PCS) in order to establish independent clusters on this criterion (Amossé et al., 2014); three groups of workers were studied: 1) upper-grade white-collar workers and professionals / technicians and associate professionals, 2) lower-grade white-collar workers and 3) blue-collar workers. For each group of occupational categories, clustering of the organizational variables was first performed with hierarchical cluster analysis (HCA). The aim of this method was to group the 16 organizational variables selected into 
homogeneous clusters, thus creating a synthetic quantitative variable for each cluster of variables identified (Chavent et al., 2012; Kuentz-Simonet et al., 2012). The dendrogram of variables and plot of aggregation levels were used to decide the number of clusters to be retained (Appendix A). The stability of the partitions of variables was evaluated by a bootstrap approach (100 replication bootstrap samples, Appendix A) (Chavent et al., 2012; Kuentz-Simonet et al., 2012). Clustering of workers using the previously obtained synthetic variables was then performed using hierarchical cluster analysis (Ward's method) (Cuadras and Rao, 1993). The bootstrap resampling method was performed to test the stability of the partition of workers retained (100 replication bootstrap samples). Hierarchical cluster analysis of workers was performed on these 100 samples, and partitions in x clusters (number of clusters of workers retained in the study sample) were compared with the partition in x clusters from the study data set using the adjusted Rand index (Rand, 1971). This index ranges from 0 (no agreement) to 1 (perfect agreement). The mean adjusted Rand index was then calculated.

In the second step, clusters were compared and characterized for each occupational category according to the 16 organizational variables. Then clusters of upper-grade white-collar workers, professionals, technicians and associate professionals, lower-grade white-collar workers and blue-collar workers with similar organizational constraints were grouped to form homogeneous forms of work organization.

Forms of work organization were compared according to gender, age, occupational characteristics and symptomatic and clinically-diagnosed shoulder disorders using Chi2 tests. Finally, the associations between symptomatic and clinically-diagnosed shoulder disorders and forms of work organization were examined in five separate logistic regression models adjusted for age, separately for men and women following the recommendations for the study of MSDs (Messing et al., 2009; Silverstein et al., 2009). The five independent variables were shoulder pain of any duration during the preceding 12 months, shoulder pain lasting more than 30 days 
during the preceding 12 months, permanent shoulder pain during the preceding 12 months, shoulder pain during the preceding seven days and rotator cuff syndrome. Statistical significance was defined as a p-value lower than 0.05 .

The clustering of variables and the logistic regression models were performed using the ClustOfVar and glm packages of R software v3.0.3, respectively, and the clustering of workers with SPAD v8.

\section{Results}

\subsection{Description of the study sample}

Fifty-nine percent of the study sample were men. Subjects were mainly blue-collar workers (43\%) and worked mainly in services (59\%) and industry (36\%, mainly in the manufacturing industry), and a few were in the construction sector (6\%, Table 1). The study sample did not differ from the 382 workers excluded because of missing values with respect to gender and economic sector. However, they were younger (23.2\% were aged less than 30 years vs. $17.8 \%$ ) and more blue-collar workers were included (43.0\% vs. $34.8 \%)$.

\subsection{Clustering of variables and workers within occupational categories}

Three clusters of variables were selected for upper-grade white-collar workers, professionals, technicians and associate professionals ( $\mathrm{n}=982$, Appendices A and B). Clustering of workers was obtained with the three synthetic variables obtained by the clustering of variables, and five clusters of workers were retained, comprising 245, 275, 82, 169 and 211 workers. The mean of the adjusted Rand index obtained with 100 replications of the study sample of these occupational categories was 0.93 , which showed good stability of the partition. For lower-grade white-collar workers $(n=864)$, four clusters of variables and five clusters of workers were retained, comprising 325, 200, 121, 52 and 166 workers (mean of the adjusted Rand index $=0.86)$. For blue-collar workers $(\mathrm{n}=1395)$, four clusters of variables and three clusters of 
workers were retained, comprising 451, 564, and 380 workers (mean of the adjusted Rand index $=0.93$ ).

\subsection{Description of forms of work organization}

From the 13 clusters of workers (five for upper-grade white-collar workers, professionals, technicians and associate professionals, five for lower-grade white-collar workers and three for blue-collar workers), five homogeneous work organization groups were constituted (Appendix C). A description of the five forms of work organization according to the sixteen organizational variables is presented in Table 2.

\subsubsection{Low decision latitude with pace constraints}

One cluster of upper-grade white-collar workers, professionals, technicians and associate professionals, two clusters of lower-grade white-collar workers and one cluster of blue-collar workers were grouped to form the low decision latitude with pace constraints group (Group 1, $22 \%$ of workers). Workers in this form of work organization were more exposed to shift work, job/task rotation, pace constraints (except work dependent on customer demand) and repetitive work than the rest of the sample and they had the lowest decision authority and skill discretion scores.

In terms of occupational category, this form of work organization had more skilled industrial blue-collar workers and unskilled industrial blue-collar workers than the whole sample. Younger workers, workers who worked in the industry sector (manufacturing industries) and workers who worked in companies with more than 200 workers were more common in this form of work organization (Table 3). Moreover there were twice as many temporary workers than in the whole sample.

\subsubsection{Medium decision latitude with pace constraints}


Workers in the second form of work organization (Group 2) represented 12\% of the study sample. Decision authority and skill discretion scores were not statistically different from the rest of the sample. They were more exposed to work pace dependent on colleagues' work, and to quantified targets and customer demand than the rest of the sample.

Intermediate administrative occupations in private companies, technicians and associate professionals and employees of corporate administrative services were more numerous in this form of work organization than in the whole sample. Women, workers who worked in service industries (wholesale and retail trade; hotels and restaurants; transport, storage and communication; financial intermediation activities; public administration; personal services), civil servants and workers who worked in companies with more than 200 workers were overrepresented.

\subsubsection{Low decision latitude with low pace constraints}

Workers in work organization Group $3(19 \%)$ had lower decision authority and skill discretion scores than the rest of the sample. Moreover, they were less exposed to the other organizational variables than the rest of the sample.

Government and public service employees and employees of corporate administrative services were more numerous in this form of work organization. Women, workers who worked in service industries (financial intermediation; real estate, renting and business activities; public administration; education; human health and social activities; personal services), civil servants and workers who worked in small companies were overrepresented.

\subsubsection{High decision latitude with pace constraints}

Workers in work organization Group 4 (17\%) had more job/task rotation, more decision authority and skill discretion and were more often exposed to pace constraints (except work dependent on paced work/automatic rate) than the rest of the sample. 
Professionals (administrative, managerial and technical occupations), technicians and associate professionals, skilled industrial blue-collar workers, skilled craft blue-collar workers and unskilled industrial blue-collar workers were more numerous in this form of work organization. Men, young workers, workers who worked in manufacturing industries and construction and workers who worked in small companies were also overrepresented.

\subsubsection{High decision latitude with low pace constraints}

Finally, workers in work organization Group $5(31 \%)$ had more decision authority and more skill discretion than the rest of the sample. Moreover, they were less exposed to shift work, job/task rotation, pace constraints and repetitive work than the rest of the sample.

Skilled industrial blue-collar workers and skilled craft blue-collar workers were more numerous in this form of work organization. Men, older workers, workers who worked in manufacturing industries and construction, permanent workers and workers who worked in small companies were overrepresented.

\subsection{Symptomatic and clinically-diagnosed shoulder disorders}

Workers in the low decision latitude with pace constraints group (Group 1) had significantly more shoulder pain of any duration, or permanently during the preceding 12 months or during the preceding seven days than other workers (Table 4). The same was true for shoulder pain of any duration and during the preceding seven days for men. However, men in the high decision latitude without pace constraints group (Group 5) had more permanent shoulder pain compared to other workers. Women workers in Group 1 had significantly more shoulder pain of any duration, or lasting more than 30 days or permanently during the preceding 12 months than other women workers. Women in the high decision latitude with pace constraints group (Group 4) had significantly more shoulder pain during the preceding seven days and rotator cuff syndrome than other workers. 
After adjustment for age and gender, workers in organization Groups 2, 3, and 5 had less risk of symptomatic and clinically diagnosed shoulder disorders than those in the Group 1 (Table 5). Workers in Group 4 had less risk of shoulder pain of any duration, shoulder pain lasting more than 30 days or permanent shoulder pain compared to workers in Group 1. However, there were no difference between Groups 1 and 4 for shoulder pain in the preceding seven days and rotator cuff syndrome. After adjustment for age, shoulder pain of any duration during the preceding 12 months and shoulder pain during the preceding seven days were statistically different between the five forms of work of organization in men (Table 5). Workers in organization Groups 2 to 5 had less risk of shoulder pain during the preceding 12 months compared to workers in Group 1, and workers in organization Groups 3 to 5 had less risk of shoulder pain during the preceding seven days compared to workers in Group 1. For women, symptomatic and clinically-diagnosed shoulder disorders differed according to the forms of work organization (Table 5). Women in organization Groups 2, 3 and 5 had less risk of symptomatic and clinically diagnosed shoulder disorders than those in Group 1. No statistical differences were observed between workers in Groups 1 and 4.

\section{Discussion}

This study identified five forms of work organization in a sample of French workers: low decision latitude with pace constraints (Group 1), medium decision latitude with pace constraints (Group 2), low decision latitude with low pace constraints (Group 3), high decision latitude with pace constraints (Group 4) and high decision latitude with low pace constraints (Group 5). Associations between forms of work organization and shoulder pain of any duration during the preceding 12 months and shoulder pain during the preceding seven days were revealed for men after adjustment for age. More men workers in Group 1 had shoulder pain than workers in the other work organization groups (except for workers in Group 2 with 
shoulder pain during the preceding seven days). More women workers in Group 1 had symptomatic and clinically-diagnosed shoulder disorders compared to other workers, except for workers in Group 4. Indeed, more workers in this form of work organization had shoulder pain during the preceding seven days and clinically-diagnosed shoulder disorders than workers in Group 1 (not statistically significant). This confirmed our hypothesis; workers in forms of work organization with high organizational constraints (Group 1 and Group 4) had more shoulder disorders than other workers, especially in women.

Work organization includes multiple nested dimensions that require simultaneous study. A few studies have identified forms of work organization based on several variables using classification methods (Amossé and Coutrot, 2008; Amossé et al., 2014; Carayon, 1994; Daubas-Letourneux and Thébaud-Mony, 2002; Engkvist et al., 2001; Härenstam et al., 2004; Leijon et al., 2006; Lorenz and Valeyre, 2005; Valeyre, 2006; Valeyre et al., 2009). However, to our knowledge, few studies have identified forms of work organization and compared them to musculoskeletal health (Daubas-Letourneux and Thébaud-Mony, 2002; Engkvist et al., 2001; Leijon et al., 2006; Valeyre, 2006). Comparison of the five forms of work organization identified in our study with existing studies was difficult because of the different variables and levels studied (worker (Carayon, 1994; Daubas-Letourneux and Thébaud-Mony, 2002; Engkvist et al., 2001; Leijon et al., 2006; Lorenz and Valeyre, 2005; Valeyre, 2006; Valeyre et al., 2009) or company (Amossé et al., 2014; Härenstam et al., 2004)). In our study, the low decision latitude with pace constraints group (Group 1) was heavily exposed to organizational factors (shift work, job/task rotation, pace constraints, repetitiveness of tasks, low decision authority and low skill discretion) and had higher risk of shoulder pain than other forms of work organization. This form was close to the work in automation form of Daubas-Letourneux et al. (Daubas-Letourneux and Thébaud-Mony, 2002) and the Taylorist form of Valeyre et al. (Lorenz and Valeyre, 2005; Valeyre, 2006; Valeyre et al., 2009). These studies also found that 
musculoskeletal health, including neck and shoulder pain, was poorer with this form of work organization. The low decision latitude with low pace constraints group (Group 3) was characterized by lower exposure to all organizational variables and had one of the lowest rates of symptomatic and clinically-diagnosed shoulder disorders. The traditional or simple structure form in Valeyre's study also showed underrepresentation of organizational variables (Lorenz and Valeyre, 2005; Valeyre, 2006; Valeyre et al., 2009), and the likelihood of reporting neck and shoulder pain was lower compared to the Taylorist form (Valeyre, 2006). The high decision latitude with pace constraints (Group 4) and high decision latitude with low pace constraints groups of work organization (Group 5) represented half of the study sample; workers had high decision authority, high skill discretion and low repetitiveness of tasks. However, workers in Group 4 were more often exposed to job/task rotation and pace constraints. Group 5 was close to the discretionary learning form of Valeyre et al. (Lorenz and Valeyre, 2005; Valeyre, 2006; Valeyre et al., 2009), and authors showed that musculoskeletal health was better with this form of work organization compared to the Taylorist form. In our study, workers with this form of work organization (Group 5) had fewer symptomatic and clinically-diagnosed shoulder disorders compared to the workers in Group 1, especially women.

All economic sectors were represented in the five work organization groups. This is in accordance with the European Working Conditions Survey which showed that industrial constraints have spread among service workers and commercial constraints among industrial workers (European Foundation for the Improvement of Living and Working Conditions, 2003). As in the literature (Daubas-Letourneux and Thébaud-Mony, 2002; Lorenz and Valeyre, 2005; Valeyre, 2006; Valeyre et al., 2009), the agriculture sector was excluded from our analyses due to the particular work organization features of this sector.

The sample was constituted through the voluntary participation of a regional network of OPs. The 83 OPs who participated (18\%) had professional characteristics similar to the 370 who did 
not participate. The random selection of workers during their mandatory occupational health examination was designed to ensure a representative sample of the region's workforce. This objective was achieved, with the exception that women were slightly underrepresented, and skilled and unskilled workers were somewhat overrepresented (Roquelaure et al., 2006).

The data used in our study are more than 10 years old, and some issues which are relevant today were not collected. No questions were asked about the use of quality standards, self-assessment of the quality of work, collective activity, or managerial practices (such as rewards reflecting effort at work, opportunity to express points of view). Moreover, the way in which the job/task rotation was assessed did not reveal how it was implemented. Further research is needed to design questionnaires to assess workers' activity and movements in performing job/task rotation more precisely. To reduce classification errors, standardized and validated instruments such as the Job Content Questionnaire, the Nordic-style questionnaire and the criteria document for the evaluation of work-related MSDs were used to assess occupational and medical data. However, findings were assessed at the worker level and no information was available at the company level. It can be argued that the worker's perception of his work is not the same as that of the company director. Moreover, a company director knows the work prescribed but this does not match the work actually performed by the worker (St-Vincent et al., 2014). The Reponse study showed that workers' perceptions were close to those of the director. However, the presence of the unions influenced the feelings of workers (Amossé and Coutrot, 2008). Furthermore, our findings were based on only one French region in which the socioeconomic structure is diversified and close to that of France as a whole (Ha et al., 2009).

Clustering of variables was preferred to multiple correspondence analysis (MCA) as adopted in other studies (Daubas-Letourneux and Thébaud-Mony, 2002; Lorenz and Valeyre, 2005; Valeyre, 2006; Valeyre et al., 2009). Indeed, the method used in this study classified variables into homogeneous groups without orthogonality constraints, which is not possible with MCA 
(Chavent et al., 2012). The study of Kuentz-Simonet el al. compared the two methods and concluded that, although the two methods provide close internal validity markers, interpretation is easier with the clustering of variables (Kuentz-Simonet et al., 2012).

From a practical point of view for the ergonomist, the study tried to capture the complexity of the forms of work organization. It identified five forms of work organization in a sample of workers: low decision latitude with pace constraints, medium decision latitude with pace constraints, low decision latitude with low pace constraints, high decision latitude with pace constraints and high decision latitude with low pace constraints. The results showed that the form of work organization close to the Taylorism form (low decision latitude with pace constraints) was associated with higher risk of shoulder disorders. Moreover, forms of work organization with pace constraints, even when they allow high decision latitude (high decision latitude with pace constraints), also had high levels of shoulder disorders in women. This means that even with decision latitude, being exposed to pace constraints is harmful for shoulder disorders.

It is necessary to identify what forms of work organization are most detrimental in order to implement preventive actions for exposed workers. Understanding the chain of determinants of shoulder disorders and MSDs in general is a key stage in prevention intervention (Roquelaure, 2016), and this study tried to identify forms of work organization associated with MSDs. However, the cross-sectional design of the study limits a causal conclusion. We recommend that future ergonomic and epidemiological studies adopt a longitudinal design and access more data on the work organization to refine forms of work organization further and to allow more precise analysis of the relationships between exposure to biomechanical, psychosocial and individual risk factors and musculoskeletal health. 
Conflict of interest: None.

Ethics approval: All workers completed an informed consent form and the study received approval from France's National Committee for Data Protection (Commission Nationale de l'Informatique et des Libertés).

Acknowledgments: We thank all the occupational physicians involved in the sentinel network and Doreen Raine for revising the English manuscript. This study was supported by the French Public Health Agency, Saint-Maurice, France (Grant 9/25/2002e5 “réseau expérimental de surveillance des troubles musculo-squelettiques"). 


\section{References}

Amossé, T., Coutrot, T., 2008. En guise de conclusion. L'évolution des modèles socioproductifs en France depuis 15 ans : le néotaylorisme n'est pas mort, in: Les relations sociales en entreprise Un portrait à partir des enquêtes « Relations professionnelles et négociations d'entreprise ». pp. $423-451$.

Amossé, T., Wolff, L., Cartron, D., Castell, L., Célérier, S., Zara-Meylan, V., 2014. Formes d'organisation et santé au travail en entreprise - Configurations d'organisation du travail et risques professionnels en entreprise (2005-2011). Available at http://travailemploi.gouv.fr/IMG/pdf/Colloque_REPONSE_Session_2_2.pdf (accessed July 29,2016).

Askenazy, P., Caroli, E., 2010. Innovative Work Practices, Information Technologies, and Working Conditions: Evidence for France. Industrial Relations: A Journal of Economy and Society 49, 544-565. doi:10.1111/j.1468-232X.2010.00616.x

Askenazy, P., Vincent Marcus, C., Caroli, E., 2002. New Organizational Practices and Working Conditions. Recherches économiques de Louvain 68, 91-110. doi:10.3917/rel.681.0091

Assurance maladie - Risques professionnels, 2015. Rapport de gestion 2014.

Bellemare, M., Marier, M., Montreuil, S., Allard, D., Prévost, J., 2002. La transformation des situations de travail par une approche participative en ergonomie : une recherche intervention pour la prévention des troubles musculo-squelettiques (No. Études et recherches / Rapport R-292). IRSST, Montréal.

Bodin, J., Ha, C., Chastang, J.-F., Descatha, A., Leclerc, A., Goldberg, M., Imbernon, E., Roquelaure, Y., 2012a. Comparison of risk factors for shoulder pain and rotator cuff syndrome in the working population. Am. J. Ind. Med. 55, 605-615. doi:10.1002/ajim.22002

Bodin, J., Ha, C., Petit Le Manac'h, A., Sérazin, C., Descatha, A., Leclerc, A., Goldberg, M., Roquelaure, Y., 2012b. Risk factors for incidence of rotator cuff syndrome in a large working population. Scand J Work Environ Health 38, 436-46. doi:10.5271/sjweh.3285 
Bodin, J., Ha, C., Sérazin, C., Descatha, A., Leclerc, A., Goldberg, M., Roquelaure, Y., 2012c. Effects of Individual and Work-related Factors on Incidence of Shoulder Pain in a Large Working Population. J Occup Health 54, 278-88.

Bongers, P.M., Ijmker, S., van den Heuvel, S., Blatter, B.M., 2006. Epidemiology of work related neck and upper limb problems: psychosocial and personal risk factors (part I) and effective interventions from a bio behavioural perspective (part II). J Occup Rehabil 16, 279-302. doi:10.1007/s10926-006-9044-1

Brännmark, M., Håkansson, M., 2012. Lean production and work-related musculoskeletal disorders: overviews of international and Swedish studies. Work 41 Suppl 1, 2321-2328. doi:10.3233/WOR-2012-0459-2321

Carayon, P., 1994. Stressful jobs and non-stressful jobs: a cluster analysis of office jobs. Ergonomics 37, 311-323. doi:10.1080/00140139408963648

Carayon, P., Smith, M.J., Haims, M.C., 1999. Work organization, job stress, and work-related musculoskeletal disorders. Hum Factors 41, 644-663. doi:10.1518/001872099779656743

Caroly, S., Coutarel, F., Landry, A., Mary-Cheray, I., 2010. Sustainable MSD prevention: management for continuous improvement between prevention and production. Ergonomic intervention in two assembly line companies. Appl Ergon 41, 591-599. doi:10.1016/j.apergo.2009.12.016

Chavent, M., Kuentz, V., Liquet, B., Saracco, J., 2012. ClustOfVar: An R Package for the Clustering of Variables. Journal of Statistical Software 50, 1-16.

Coutrot, T., 1998. L'entreprise néo-libérale, nouvelle utopie capitaliste? Enquête sur les modes d'organisation du travail, Textes à l'appui. Découverte, Paris.

Cuadras, C.M., Rao, C.R., 1993. Multivariate Analysis: Future Directions 2. Elsevier.

Daubas-Letourneux, V., Thébaud-Mony, A., 2002. Organisation du travail et santé dans l'Union européenne, Fondation européenne pour l'amélioration des conditions de Vie et de Travail en Europe. Dublin.

Drago, R., 1995. "The New American Workplace” by Eileen Appelbaum and Rosemary Batt: A Review. Journal of Post Keynesian Economics 17, 515-524. doi:10.1080/01603477.1995.11490047 
Engkvist, I.-L., Kjellberg, A., Wigaeus, H.E., Hagberg, M., Menckel, E., Ekenvall, L., 2001. Back injuries among nursing personnel — identification of work conditions with cluster analysis. Safety Science 37, 1-18. doi:10.1016/S0925-7535(00)00039-4

European Foundation for the Improvement of Living and Working Conditions, 2012. Fifth European Working Conditions Survey: Overview Report. Luxembourg: Publications Office of the European Union.

European Foundation for the Improvement of Living and Working Conditions, 2003. Time and work: work intensity. Luxembourg: Office for Official Publications of the European Communities.

Ferreira Júnior, M., Conceição, G.M., Saldiva, P.H., 1997. Work organization is significantly associated with upper extremities musculoskeletal disorders among employees engaged in interactive computer-telephone tasks of an international bank subsidiary in São Paulo, Brazil. Am. J. Ind. Med. 31, 468-473. doi:10.1002/(SICI)1097-0274(199704)31:4<468::AID-AJIM14>3.0.CO;2Y

Ha, C., Roquelaure, Y., Leclerc, A., Touranchet, A., Goldberg, M., Imbernon, E., 2009. The French Musculoskeletal Disorders Surveillance Program: Pays de la Loire network. Occup Environ Med 66, 471-479. doi:10.1136/oem.2008.042812

Hagberg, M., Silverstein, B., Wells, R., Smith, M., Hendrick, H., Carayon, P., Pérusse, M., 1995. Work related musculoskeletal disorders (WMSDs): a reference book for prevention. Taylor \& Francis, London.

Härenstam, A., Bejerot, E., Leijon, O., Schéele, P., Waldenström, K., Group, T.M.R., 2004. Multilevel analyses of organizational change and working conditions in public and private sector. Eur $\mathbf{J}$ Work Organ Psy 13, 305-343. doi:10.1080/13594320444000119

Hopman, K., Krahe, L., Lukersmith, S., McColl, A., Vine, K., 2013. Clinical practice guidelines for the management of rotator cuff syndrome in the workplace. University of New South Wales, Port Macquarie (Australia).

Karasek, R., Brisson, C., Kawakami, N., Houtman, I., Bongers, P., Amick, B., 1998. The Job Content Questionnaire (JCQ): an instrument for internationally comparative assessments of psychosocial job characteristics. J Occup Health Psychol 3, 322-355. 
Karsh, B.-T., 2006. Theories of work-related musculoskeletal disorders: Implications for ergonomic interventions. Theoretical Issues in Ergonomics Science 7, 71-88. doi:10.1080/14639220512331335160

Koukoulaki, T., 2014. The impact of lean production on musculoskeletal and psychosocial risks: an examination of sociotechnical trends over 20 years. Appl Ergon 45, 198-212. doi:10.1016/j.apergo.2013.07.018

Kuentz-Simonet, V., Lyser, S., Chavent, M., Saracco, J., Candau, J., Deuffic, P., 2012. Classification de variables qualitatives pour la compréhension de la prise en compte de l'environnement par les agriculteurs. Presented at the Les Journées de Méthodologie Statistique de l'INSEE, Paris, p. 27.

Kuijpers, T., van der Windt, D.A.W.M., van der Heijden, G.J.M.G., Bouter, L.M., 2004. Systematic review of prognostic cohort studies on shoulder disorders. Pain 109, 420-431.

Kuorinka, I., Jonsson, B., Kilbom, A., Vinterberg, H., Biering-Sørensen, F., Andersson, G., Jørgensen, K., 1987. Standardised Nordic questionnaires for the analysis of musculoskeletal symptoms. Appl Ergon 18, 233-237. doi:10.1016/0003-6870(87)90010-X

Landsbergis, P.A., Cahill, J., Schnall, P., 1999. The impact of lean production and related new systems of work organization on worker health. J Occup Health Psychol 4, 108-130.

Lazarus, R.S., 1991. Progress on a cognitive-motivational-relational theory of emotion. American Psychologist 46, 819-834. doi:10.1037/0003-066X.46.8.819

Leijon, O., Härenstam, A., Waldenström, K., Alderling, M., Vingård, E., 2006. Target groups for prevention of neck/shoulder and low back disorders: an exploratory cluster analysis of working and living conditions. Work 27, 189-204.

Lorenz, E., Valeyre, A., 2005. Organisational Innovation, Human Resource Management and Labour Market Structure: A Comparison of the EU-15. Journal of Industrial Relations 47, 424-442. doi:10.1111/j.1472-9296.2005.00183.x

Marklund, S., Bolin, M., von Essen, J., 2008. Can individual health differences be explained by workplace characteristics?â€”A multilevel analysis. Social Science \& Medicine 66, 650-662. doi:10.1016/j.socscimed.2007.09.008 
Messing, K., Stock, S.R., Tissot, F., 2009. Should studies of risk factors for musculoskeletal disorders be stratified by gender? Lessons from the 1998 Québec Health and Social Survey. Scand J Work Environ Health 35, 96-112. doi:10.5271/sjweh.1310

Niedhammer, I., Chastang, J.F., Gendrey, L., David, S., Degioanni, S., 2006. [Psychometric properties of the French version of Karasek's "Job Content Questionnaire" and its scales measuring psychological pressures, decisional latitude and social support: the results of the SUMER]. Sante Publique 18, 413-427. doi:10.3917/spub.063.0413

Rand, W.M., 1971. Objective Criteria for the Evaluation of Clustering Methods. Journal of the American Statistical Association 66, 846-850. doi:10.2307/2284239

Roquelaure, Y., 2016. Promoting a Shared Representation of Workers' Activities to Improve Integrated Prevention of Work-Related Musculoskeletal Disorders. Safety and Health at Work 7, 171-174. doi:10.1016/j.shaw.2016.02.001

Roquelaure, Y., 2015. Musculoskeletal disorders: a major challenge for occupational risk prevention in Europe. ETUI, Brussels.

Roquelaure, Y., Bodin, J., Ha, C., Petit Le Manac'h, A., Descatha, A., Chastang, J., Leclerc, A., Goldberg, M., Imbernon, E., 2011. Personal, biomechanical, and psychosocial risk factors for rotator cuff syndrome in a working population. Scand J Work Environ Health 37, 502-511. doi:10.5271/sjweh.3179

Roquelaure, Y., Ha, C., Leclerc, A., Touranchet, A., Sauteron, M., Melchior, M., Imbernon, E., Goldberg, M., 2006. Epidemiologic surveillance of upper-extremity musculoskeletal disorders in the working population. Arthritis Rheum 55, 765-778. doi:10.1002/art.22222

Sauter, S., Swanson, N., 1996. An ecological model of musculoskeletal disorders in office work, in: Beyond Biomechanics: Psychosocial Aspects of Musculoskeletal Disorders in Office Work. Taylor \& Francis, London ; Bristol, PA, pp. 3-21.

Silverstein, B., Fan, Z.J., Smith, C.K., Bao, S., Howard, N., Spielholz, P., Bonauto, D., Viikari-Juntura, E., 2009. Gender adjustment or stratification in discerning upper extremity musculoskeletal disorder risk? Scand J Work Environ Health 35, 113-126. doi:10.5271/sjweh.1309 
Sluiter, J.K., Rest, K.M., Frings-Dresen, M.H., 2001. Criteria document for evaluating the workrelatedness of upper-extremity musculoskeletal disorders. Scand J Work Environ Health 27 Suppl 1,1-102. doi:10.5271/sjweh.637

St-Vincent, M., Vézina, N., Bellemare, M., Denis, D., Ledoux, É., Imbeau, D., 2014. Ergonomic Intervention. BookBaby, Cork.

Valeyre, A., 2006. Conditions de travail et santé au travail des salariés de l'Union européenne: des situations contrastées selon les formes d'organisation (No. 73), Documents de travail du CEE. Centre d'études de l'emploi, Noisy-le-Grand.

Valeyre, A., Lorenz, E., Cartron, D., Csizmadia, P., Gollac, M., Illéssy, M., Makó, C., 2009. Working conditions in the European Union: Work organisation. Office for official publications of the European communities, «European foundation for the improvement of living and working conditions », Luxembourg.

van der Windt, D.A., Thomas, E., Pope, D.P., de Winter, A.F., Macfarlane, G.J., Bouter, L.M., Silman, A.J., 2000. Occupational risk factors for shoulder pain: a systematic review. Occup Environ Med 57, 433-442. doi:10.1136/oem.57.7.433

van Rijn, R.M., Huisstede, B.M., Koes, B.W., Burdorf, A., 2010. Associations between work-related factors and specific disorders of the shoulder--a systematic review of the literature. Scand J Work Environ Health 36, 189-201. doi:10.5271/sjweh.2895

Westgaard, R.H., Winkel, J., 2011. Occupational musculoskeletal and mental health: Significance of rationalization and opportunities to create sustainable production systems - A systematic review. Applied Ergonomics 42, 261-296. doi:10.1016/j.apergo.2010.07.002 
Table 1: Comparison of the characteristics of the workers included and excluded from the analyses

\begin{tabular}{|c|c|c|c|c|c|c|c|}
\hline & \multicolumn{2}{|c|}{ Initial sample } & \multicolumn{2}{|c|}{$\begin{array}{l}\text { Workers } \\
\text { included }\end{array}$} & \multicolumn{2}{|c|}{$\begin{array}{c}\text { Workers } \\
\text { excluded because } \\
\text { of missing values }\end{array}$} & \multirow[t]{3}{*}{$\begin{array}{c}\mathrm{p}- \\
\text { value }^{\mathrm{a}}\end{array}$} \\
\hline & \multicolumn{2}{|c|}{$\mathrm{N}=3710$} & \multicolumn{2}{|c|}{$\mathrm{N}=3241$} & \multicolumn{2}{|c|}{$\mathrm{N}=382$} & \\
\hline & $\mathrm{n}$ & $\%$ & $\mathrm{n}$ & $\%$ & $\mathrm{n}$ & $\%$ & \\
\hline Men & 2161 & 58.2 & 1899 & 58.6 & 208 & 54.5 & 0.121 \\
\hline Age (in years) & & & & & & & 0.022 \\
\hline$<30$ & 839 & 22.6 & 751 & 23.2 & 68 & 17.8 & \\
\hline $30-39$ & 1085 & 29.3 & 958 & 29.5 & 103 & 27.0 & \\
\hline $40-49$ & 1095 & 29.5 & 939 & 29.0 & 129 & 33.8 & \\
\hline$\geq 50$ & 690 & 18.6 & 593 & 18.3 & 82 & 21.5 & \\
\hline Occupational category (PCS code) & & & & & & & 0.014 \\
\hline Craftsmen, salesmen, managers & 16 & 0.4 & - & - & - & - & \\
\hline $\begin{array}{l}\text { Upper-grade white-collar workers and } \\
\text { professionals }\end{array}$ & 288 & 7.8 & 251 & 7.7 & 37 & 9.8 & \\
\hline Technicians, associate professionals & 829 & 22.4 & 731 & 22.6 & 90 & 23.9 & \\
\hline Lower-grade white-collar workers & 986 & 26.6 & 864 & 26.7 & 119 & 31.6 & \\
\hline Blue-collar workers & 1586 & 42.8 & 1395 & 43.0 & 131 & 34.8 & \\
\hline Economic sector (NAF code) & & & & & & & 0.109 \\
\hline Agriculture & 71 & 1.9 & - & - & - & - & \\
\hline Industry & 1222 & 33.0 & 1107 & 34.2 & 111 & 29.1 & \\
\hline Construction & 214 & 5.8 & 189 & 5.8 & 21 & 5.5 & \\
\hline Services & 2200 & 59.4 & 1942 & 60.0 & 250 & 65.5 & \\
\hline
\end{tabular}

${ }^{a} \mathrm{Chi} 2$ test comparing the 3241 included in the analyses to the 382 workers excluded because of missing values.

Table 2: Description of the five forms of work organization according to the sixteen

organizational variables

\begin{tabular}{|c|c|c|c|c|c|c|c|c|c|c|c|c|}
\hline & \multicolumn{2}{|c|}{ Group $1^{\mathrm{a}}$} & \multicolumn{2}{|c|}{ Group $2^{\mathrm{b}}$} & \multicolumn{2}{|c|}{ Group $3^{\mathrm{c}}$} & \multicolumn{2}{|c|}{ Group 4 ${ }^{\mathrm{d}}$} & \multicolumn{2}{|c|}{ Group $5^{\mathrm{e}}$} & \multicolumn{2}{|c|}{ Total } \\
\hline & $\mathrm{n}$ & $\%$ & $\mathrm{n}$ & $\%$ & $\mathrm{n}$ & $\%$ & $\mathrm{n}$ & $\%$ & $\mathrm{n}$ & $\%$ & $\mathrm{n}$ & $\%$ \\
\hline & 706 & 21.8 & 377 & 11.6 & 600 & 18.5 & 549 & 16.9 & 1009 & 31.1 & 3241 & 100.0 \\
\hline \multicolumn{13}{|c|}{ 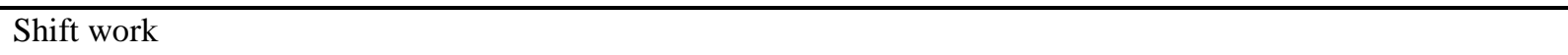 } \\
\hline No & 153 & 21.7 & 317 & 84.1 & 521 & 86.8 & 412 & 75.1 & 779 & 77.2 & 2182 & 67.3 \\
\hline Yes, non-rotating & 190 & 26.9 & 41 & 10.9 & 53 & 8.8 & 72 & 13.1 & 147 & 14.6 & 503 & 15.5 \\
\hline Yes, rotating & 363 & 51.4 & 19 & 5.0 & 26 & 4.3 & 65 & 11.8 & 83 & 8.2 & 556 & 17.2 \\
\hline Job/task rotation ( $\geq 1$ per week) & 343 & 48.6 & 114 & 30.2 & 146 & 24.3 & 230 & 41.9 & 382 & 37.9 & 1215 & 37.5 \\
\hline \multicolumn{13}{|l|}{ Work pace dependent on } \\
\hline Paced work/automatic rate & 399 & 56.5 & 3 & 0.8 & 2 & 0.3 & 74 & 13.5 & 31 & 3.1 & 509 & 15.7 \\
\hline Colleagues' work & 341 & 48.3 & 250 & 66.3 & 37 & 6.2 & 241 & 43.9 & 156 & 15.5 & 1025 & 31.6 \\
\hline Quant & 503 & 71.3 & 300 & 79.6 & 65 & 10.8 & 401 & 73.0 & 293 & 29.0 & 1562 & 48.2 \\
\hline ent controls or surveillance & 399 & 56.5 & 77 & 20.4 & 51 & 8.5 & 185 & 33.7 & 137 & 13.6 & 849 & 26.2 \\
\hline Customer demand & 173 & 24.5 & 338 & 89.7 & 196 & 32.7 & 533 & 97.1 & 210 & 20.8 & 1450 & 44.7 \\
\hline \multicolumn{13}{|l|}{ High repetitiveness of tasks } \\
\hline No & 197 & 27.9 & 278 & 73.7 & 474 & 79.0 & 350 & 63.8 & 695 & 68.9 & 1994 & 61.5 \\
\hline & 128 & 18.1 & 37 & 9.8 & 44 & 7.3 & 79 & 14.4 & 116 & 11.5 & 404 & 12.5 \\
\hline$\geq 4 \mathrm{~h} /$ day & 381 & 54.0 & 62 & 16.5 & 82 & 13.7 & 120 & 21.9 & 198 & 19.6 & 843 & 26.0 \\
\hline
\end{tabular}




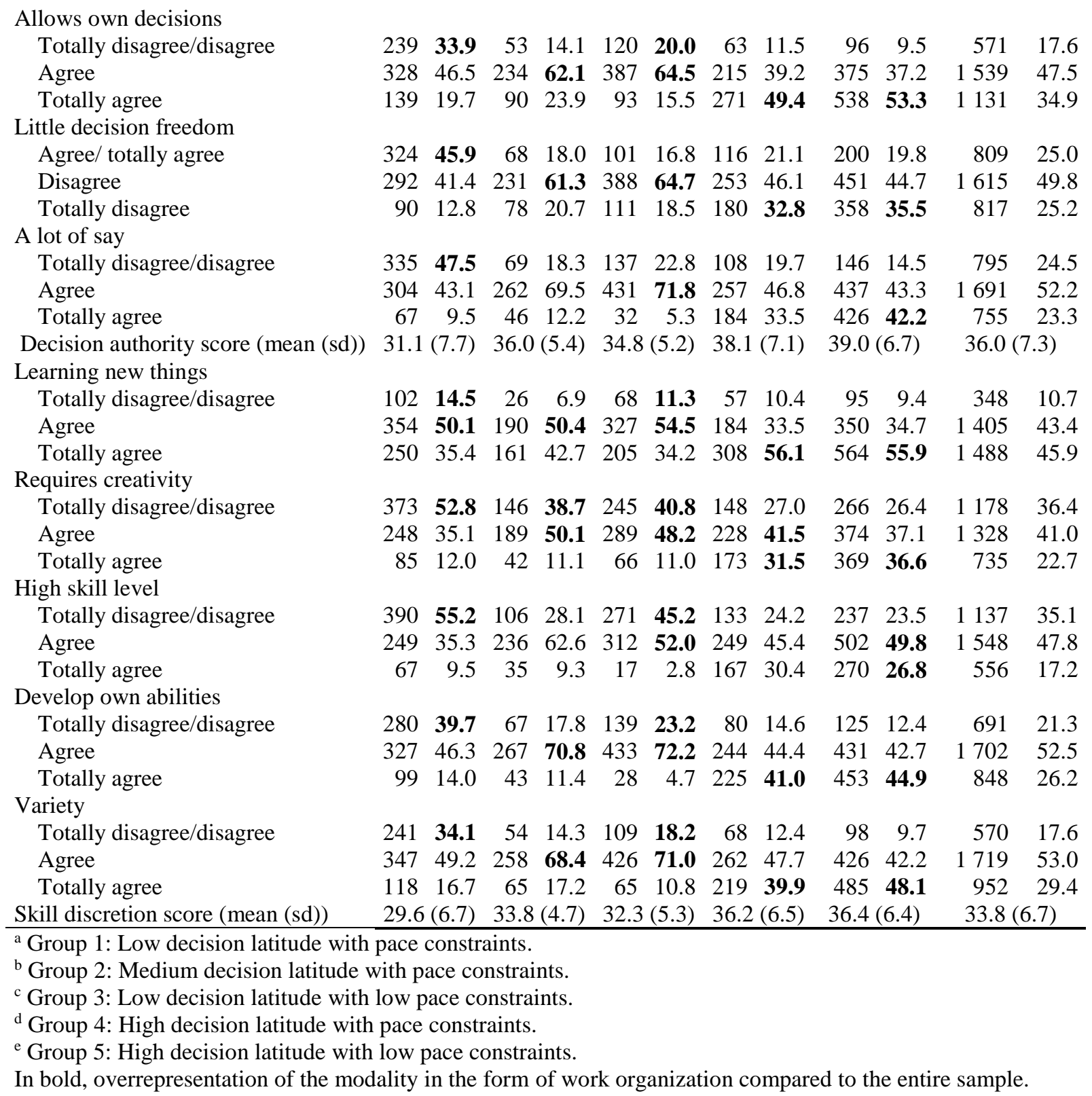


Table 3: Description of the five forms of work organization according to gender, age,

occupational category, economic sector and type of contract

\begin{tabular}{|c|c|c|c|c|c|c|c|c|c|c|c|c|c|}
\hline & \multicolumn{2}{|c|}{ Group $1^{\mathrm{a}}$} & \multicolumn{2}{|c|}{ Group $2^{b}$} & \multicolumn{2}{|c|}{ Group $3^{c}$} & \multicolumn{2}{|c|}{ Group $4^{\mathrm{d}}$} & \multicolumn{2}{|c|}{ Group $5^{\mathrm{e}}$} & \multicolumn{2}{|c|}{ Total } & \multirow{3}{*}{$\mathrm{p}^{\mathrm{f}}$} \\
\hline & $\mathrm{n}$ & $\%$ & $\mathrm{n}$ & $\%$ & $\mathrm{n}$ & $\%$ & $\mathrm{n}$ & $\%$ & $\mathrm{n}$ & $\%$ & $\mathrm{n}$ & $\%$ & \\
\hline & 706 & 21.8 & 377 & 11.6 & 600 & 18.5 & 549 & 16.9 & 1009 & 31.1 & 3241 & 100.0 & \\
\hline Men & 395 & 56.0 & 175 & 46.4 & 215 & 35.8 & 443 & 80.7 & 671 & 66.5 & 1899 & 58.6 & $<0.0001$ \\
\hline Age (in years) & & & & & & & & & & & & & $<0.0001$ \\
\hline$<30$ & 202 & 28.6 & 80 & 21.2 & 120 & 20.0 & 157 & 28.6 & 192 & 19.0 & 751 & 23.2 & \\
\hline $30-49$ & 227 & 32.2 & 106 & 28.1 & 175 & 29.2 & 161 & 29.3 & 289 & 28.6 & 958 & 29.6 & \\
\hline $40-49$ & 180 & 25.5 & 126 & 33.4 & 189 & 31.5 & 147 & 26.8 & 297 & 29.4 & 939 & 29.0 & \\
\hline$\geq 50$ & 97 & 13.7 & 65 & 17.2 & 116 & 19.3 & 84 & 15.3 & 231 & 22.9 & 593 & 18.3 & \\
\hline Occupational category & & & & & & & & & & & & & $<0.0001$ \\
\hline $\begin{array}{l}\text { Upper-grade white-collar } \\
\text { workers and professionals }\end{array}$ & 5 & 0.7 & 46 & 12.2 & 60 & 10.0 & 60 & 10.9 & 80 & 7.9 & 251 & 7.7 & \\
\hline $\begin{array}{l}\text { Technicians. associate } \\
\text { professionals }\end{array}$ & 77 & 10.9 & 165 & 43.8 & 215 & 35.8 & 109 & 19.9 & 165 & 16.4 & 731 & 22.6 & \\
\hline $\begin{array}{l}\text { Lower-grade white-collar } \\
\text { workers }\end{array}$ & 173 & 24.5 & 166 & 44.0 & 325 & 54.2 & 0 & 0.0 & 200 & 19.8 & 864 & 26.7 & \\
\hline Blue-collar workers & 451 & 63.9 & 0 & 0.0 & 0 & 0.0 & 380 & 69.2 & 564 & 55.9 & 1395 & 43.0 & \\
\hline Economic sector & & & & & & & & & & & & & $<0.0001$ \\
\hline Industry & 361 & 51.2 & 82 & 21.8 & 98 & 16.3 & 197 & 36.0 & 369 & 36.6 & 1107 & 34.2 & \\
\hline Construction & 11 & 1.6 & 9 & 2.4 & 14 & 2.3 & 48 & 8.8 & 107 & 10.6 & 189 & 5.8 & \\
\hline Services & 333 & 47.2 & 286 & 75.9 & 488 & 81.3 & 303 & 55.3 & 532 & 52.8 & 1942 & 60.0 & \\
\hline Type of contract & & & & & & & & & & & & & $<0.0001$ \\
\hline Permanent & 501 & 71.1 & 257 & 68.2 & 422 & 70.8 & 436 & 79.7 & 801 & 79.5 & 2417 & 74.8 & \\
\hline Civil servant & 66 & 9.4 & 93 & 24.7 & 128 & 21.5 & 49 & 9.0 & 110 & 10.9 & 446 & 13.8 & \\
\hline Precarious & 46 & 6.5 & 22 & 5.8 & 39 & 6.5 & 25 & 4.6 & 61 & 6.1 & 193 & 6.0 & \\
\hline Temporary & 92 & 13.1 & 5 & 1.3 & 7 & 1.2 & 37 & 6.8 & 35 & 3.5 & 176 & 5.5 & \\
\hline Size of company & & & & & & & & & & & & & $<0.0001$ \\
\hline 1 to 9 & 33 & 4.8 & 29 & 7.9 & 97 & 16.6 & 88 & 16.3 & 167 & 17.0 & 414 & 13.1 & \\
\hline 10 to 49 & 57 & 8.2 & 70 & 19.0 & 112 & 19.2 & 133 & 24.6 & 199 & 20.3 & 571 & 18.0 & \\
\hline 50 to 199 & 101 & 14.5 & 40 & 10.9 & 65 & 11.1 & 75 & 13.9 & 177 & 18.0 & 458 & 14.5 & \\
\hline$\geq 200$ & 504 & 72.5 & 229 & 62.2 & 311 & 53.2 & 244 & 45.2 & 438 & 44.7 & 1726 & 54.5 & \\
\hline
\end{tabular}

${ }^{\mathrm{a}}$ Group 1: Low decision latitude with pace constraints.

${ }^{\mathrm{b}}$ Group 2: Medium decision latitude with pace constraints.

${ }^{\mathrm{c}}$ Group 3: Low decision latitude with low pace constraints.

${ }^{\mathrm{d}}$ Group 4: High decision latitude with pace constraints.

${ }^{\text {e }}$ Group 5: High decision latitude with low pace constraints.

${ }^{\mathrm{f}} \mathrm{Chi} 2$ test comparing gender, age and occupational characteristics according to the forms of work organization. 
Table 4: Prevalence of symptomatic and clinically diagnosed shoulder disorders according to

the five forms of work organization

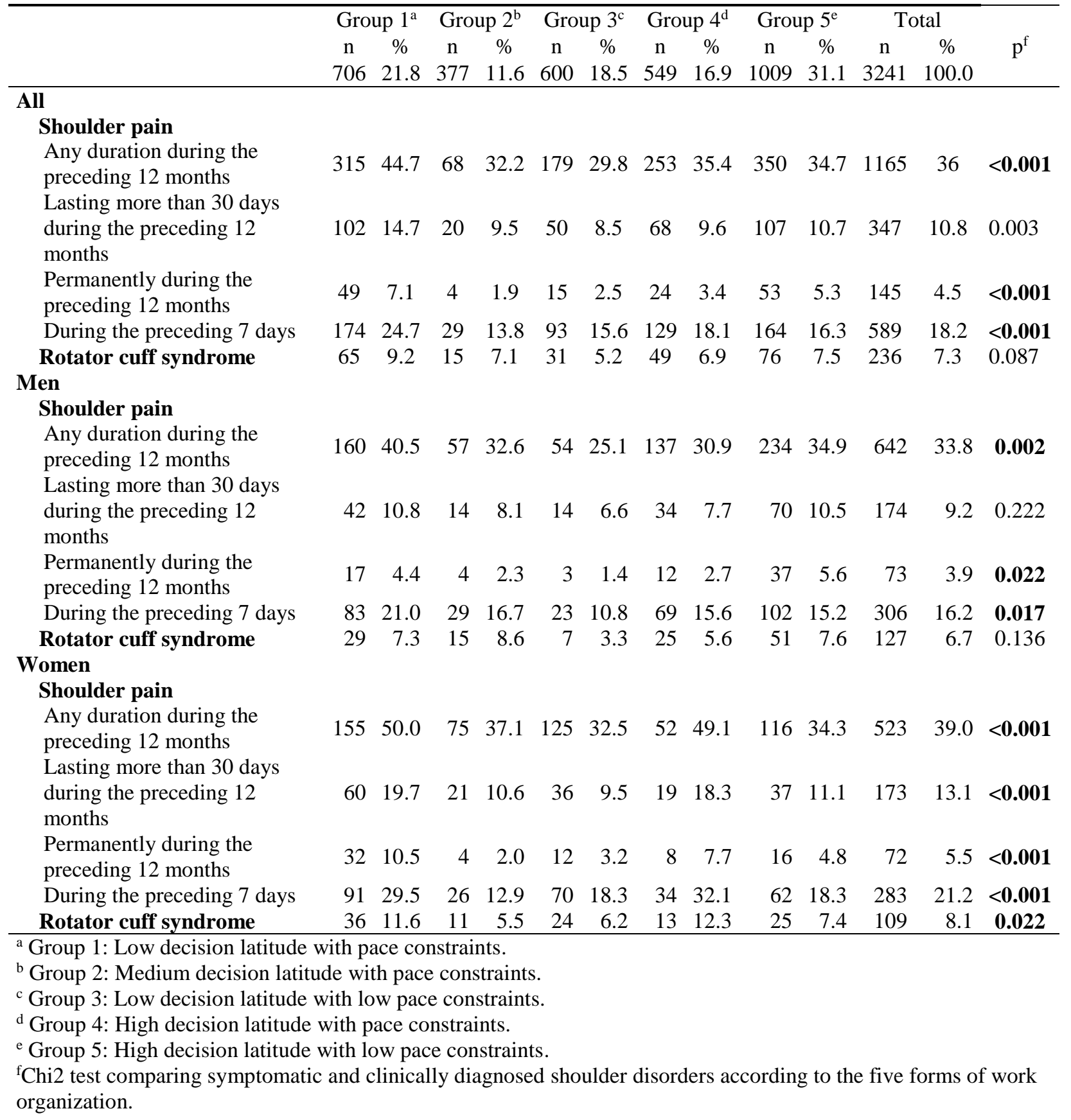


Table 5: Associations between the five forms of work organization and symptomatic and

clinically diagnosed shoulder disorders

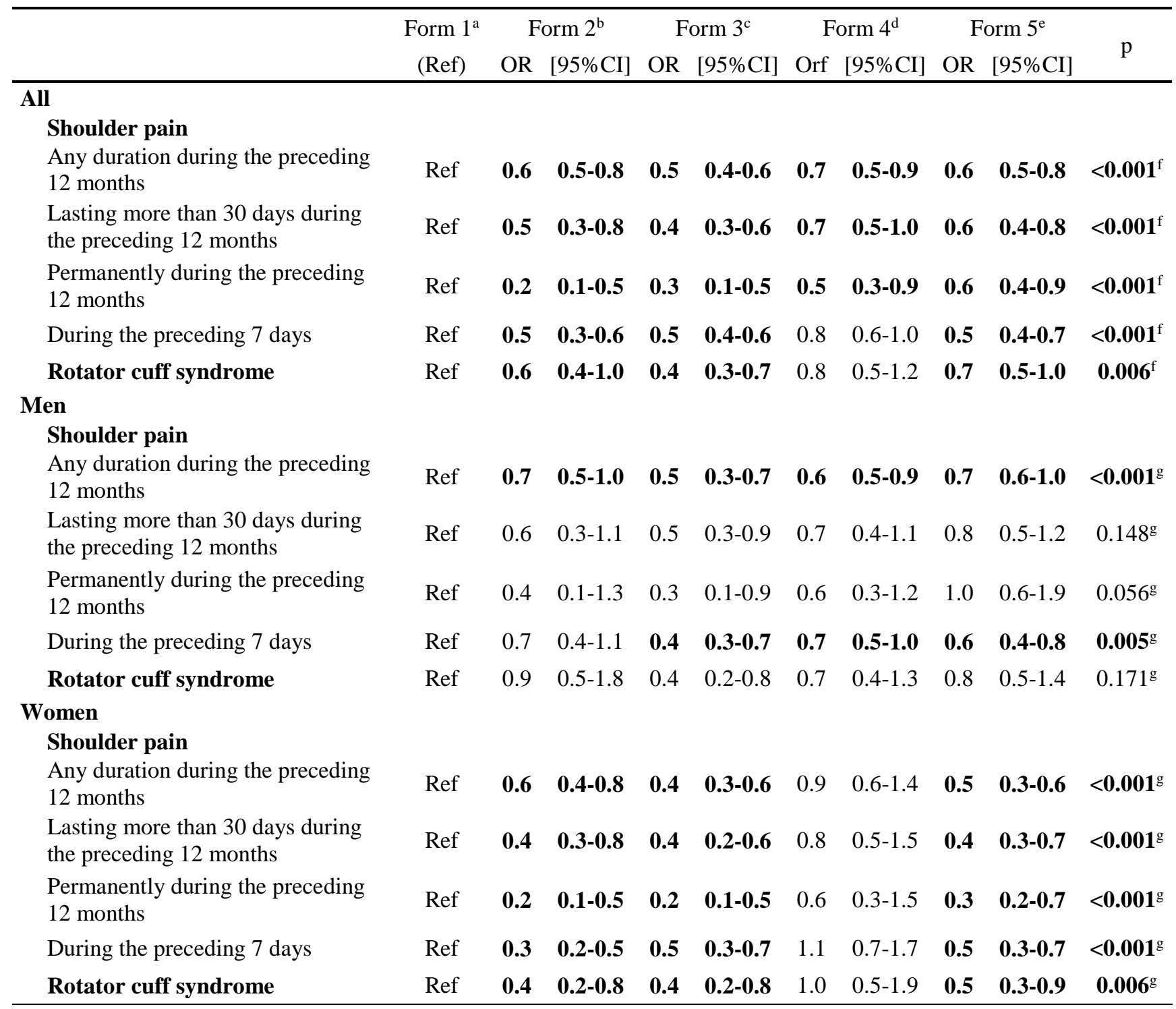

${ }^{\mathrm{a}}$ Form 1: Low decision latitude with pace constraints.

${ }^{b}$ Form 2: Medium decision latitude with pace constraints.

${ }^{c}$ Form 3: Low decision latitude with low pace constraints.

${ }^{\mathrm{d}}$ Form 4: High decision latitude with pace constraints.

eForm 5: High decision latitude with low pace constraints.

${ }^{\mathrm{f}}$ Adjusted for age and gender.

${ }^{\mathrm{g}}$ Adjusted for age. 
Appendix A: Clustering of variables according to occupational category. A.1: dendrogram of variables. A.2: plot of aggregation levels. A.3: stability of the partitions of variables.

Upper white-collar, professionals, technicians and associate professionals $(n=982)$

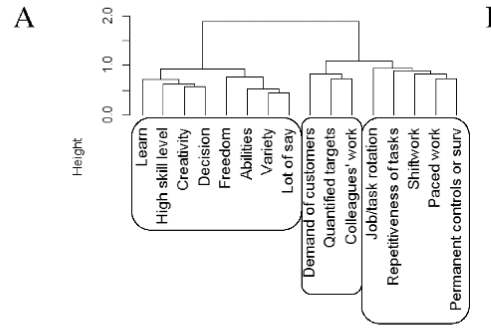

B

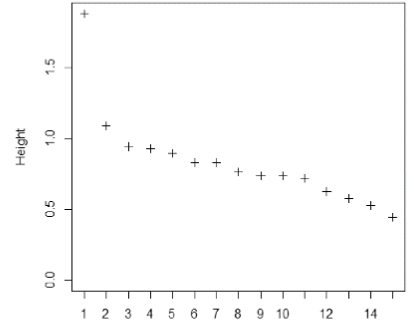

number of clusters

Lower-grade white-collar workers $(n=864)$

A

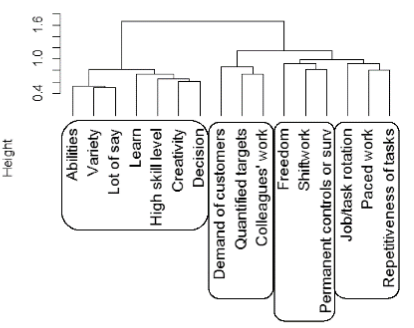

Blue-collar workers $(\mathbf{n}=\mathbf{1 3 9 5})$

A

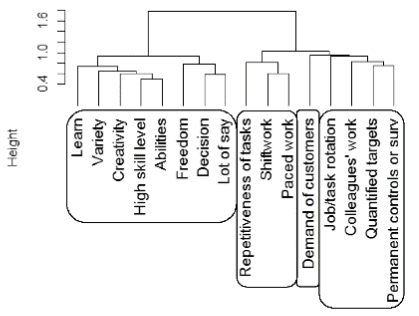

B

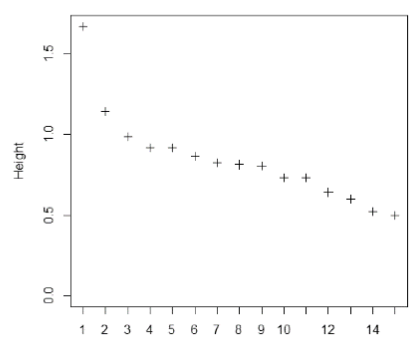

number of clusters

B

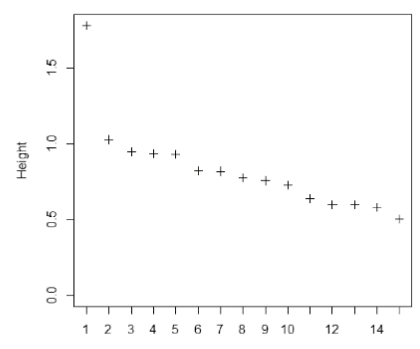

$\mathrm{C}$

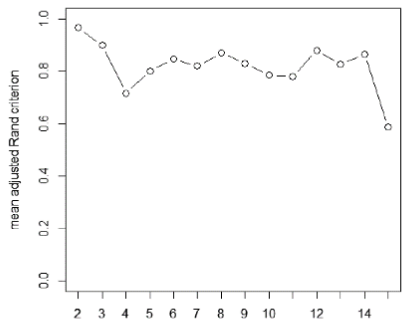

number of clusters

$\mathrm{C}$

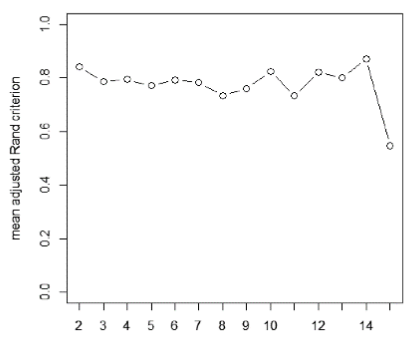

number of clusters

$\mathrm{C}$

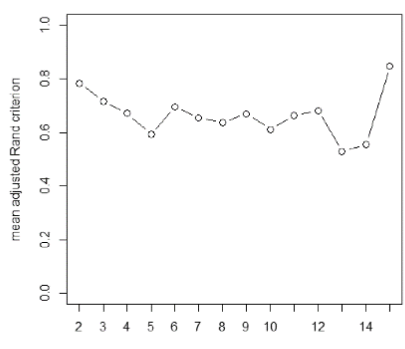

Decision: Allows own decisions; Learn: Learn new things; Creativity: Requires creativity; Abilities: Develop own abilities; Paced work: Paced work or work pace dependent on automatic rate; Colleagues' work: Work pace dependent on colleagues' work; Quantified targets: Work pace dependent on quantified targets; Permanent controls or surv: Work pace dependent on permanent controls or surveillance; Repetitiveness of tasks: High repetitiveness of tasks. 
Appendix B: Clustering of variables according to occupational category

\begin{tabular}{|c|c|c|c|c|c|c|}
\hline & \multicolumn{2}{|c|}{$\begin{array}{l}\text { Upper-grade white-collar } \\
\text { workers and } \\
\text { professionals/Technicians, } \\
\text { associate professionals }\end{array}$} & \multicolumn{2}{|c|}{$\begin{array}{l}\text { Lower-grade white-collar } \\
\text { workers }\end{array}$} & \multicolumn{2}{|c|}{ Blue-collar workers } \\
\hline & Variable & $\eta^{2 \mathrm{a}}$ & Variable & $\eta^{2 \mathrm{a}}$ & Variable & $\eta^{2 \mathrm{a}}$ \\
\hline $\mathrm{N}$ & 982 & & 864 & & 1395 & \\
\hline $\begin{array}{l}\text { Number of } \\
\text { clusters }\end{array}$ & 3 & & 4 & & 4 & \\
\hline \multirow[t]{5}{*}{ Cluster 1} & Shift work & 0.27 & Shift work & 0.41 & Shift work & 0.61 \\
\hline & $\begin{array}{l}\text { Permanent } \\
\text { controls/surveillance }\end{array}$ & 0.46 & $\begin{array}{l}\text { Permanent } \\
\text { controls/surveillance }\end{array}$ & 0.54 & $\begin{array}{l}\text { Paced } \\
\text { work/automatic rate }\end{array}$ & 0.60 \\
\hline & $\begin{array}{l}\text { Paced } \\
\text { work/automatic rate }\end{array}$ & 0.49 & Freedom & 0.32 & $\begin{array}{l}\text { High repetitiveness } \\
\text { of tasks }\end{array}$ & 0.37 \\
\hline & $\begin{array}{l}\text { Job/task rotation }(\geq 1 \\
\text { per week) }\end{array}$ & 0.14 & & & & \\
\hline & $\begin{array}{l}\text { High repetitiveness } \\
\text { of tasks }\end{array}$ & 0.24 & & & & \\
\hline \multirow[t]{8}{*}{ Cluster 2} & Learn new things & 0.32 & Learn new things & 0.34 & Learn new things & 0.28 \\
\hline & Requires creativity & 0.41 & Requires creativity & 0.42 & Requires creativity & 0.46 \\
\hline & $\begin{array}{l}\text { Allows own } \\
\text { decisions }\end{array}$ & 0.51 & $\begin{array}{l}\text { Allows own } \\
\text { decisions }\end{array}$ & 0.47 & $\begin{array}{l}\text { Allows own } \\
\text { decisions }\end{array}$ & 0.51 \\
\hline & High skill level & 0.35 & High skill level & 0.41 & High skill level & 0.43 \\
\hline & Variety & 0.49 & Variety & 0.51 & Variety & 0.46 \\
\hline & A lot of say & 0.54 & A lot of say & 0.45 & A lot of say & 0.37 \\
\hline & $\begin{array}{l}\text { Develop own } \\
\text { abilities }\end{array}$ & 0.57 & $\begin{array}{l}\text { Develop own } \\
\text { abilities }\end{array}$ & 0.59 & $\begin{array}{l}\text { Develop own } \\
\text { abilities }\end{array}$ & 0.60 \\
\hline & Freedom & 0.22 & & & Freedom & 0.11 \\
\hline \multirow[t]{3}{*}{ Cluster 3} & Customer demand & 0.40 & Customer demand & 0.35 & Customer demand & 1.00 \\
\hline & Colleagues' work & 0.49 & Colleagues' work & 0.51 & & \\
\hline & Quantified targets & 0.54 & Quantified targets & 0.54 & & \\
\hline \multirow[t]{4}{*}{ Cluster 4} & & & $\begin{array}{l}\text { Job/task rotation }(\geq 1 \\
\text { per week) }\end{array}$ & 0.29 & $\begin{array}{l}\text { Job/task rotation }(\geq 1 \\
\text { per week) }\end{array}$ & 0.18 \\
\hline & & & $\begin{array}{l}\text { Paced } \\
\text { work/automatic rate }\end{array}$ & 0.48 & Colleagues' work & 0.42 \\
\hline & & & $\begin{array}{l}\text { High repetitiveness } \\
\text { of tasks }\end{array}$ & 0.50 & Quantified targets & 0.45 \\
\hline & & & & & $\begin{array}{l}\text { Permanent } \\
\text { controls/surveillance }\end{array}$ & 0.43 \\
\hline
\end{tabular}

\footnotetext{
${ }^{\text {a }}$ Correlation ratio with the quantitative synthetic variable.
} 
Appendix C: Aggregation of clusters of workers

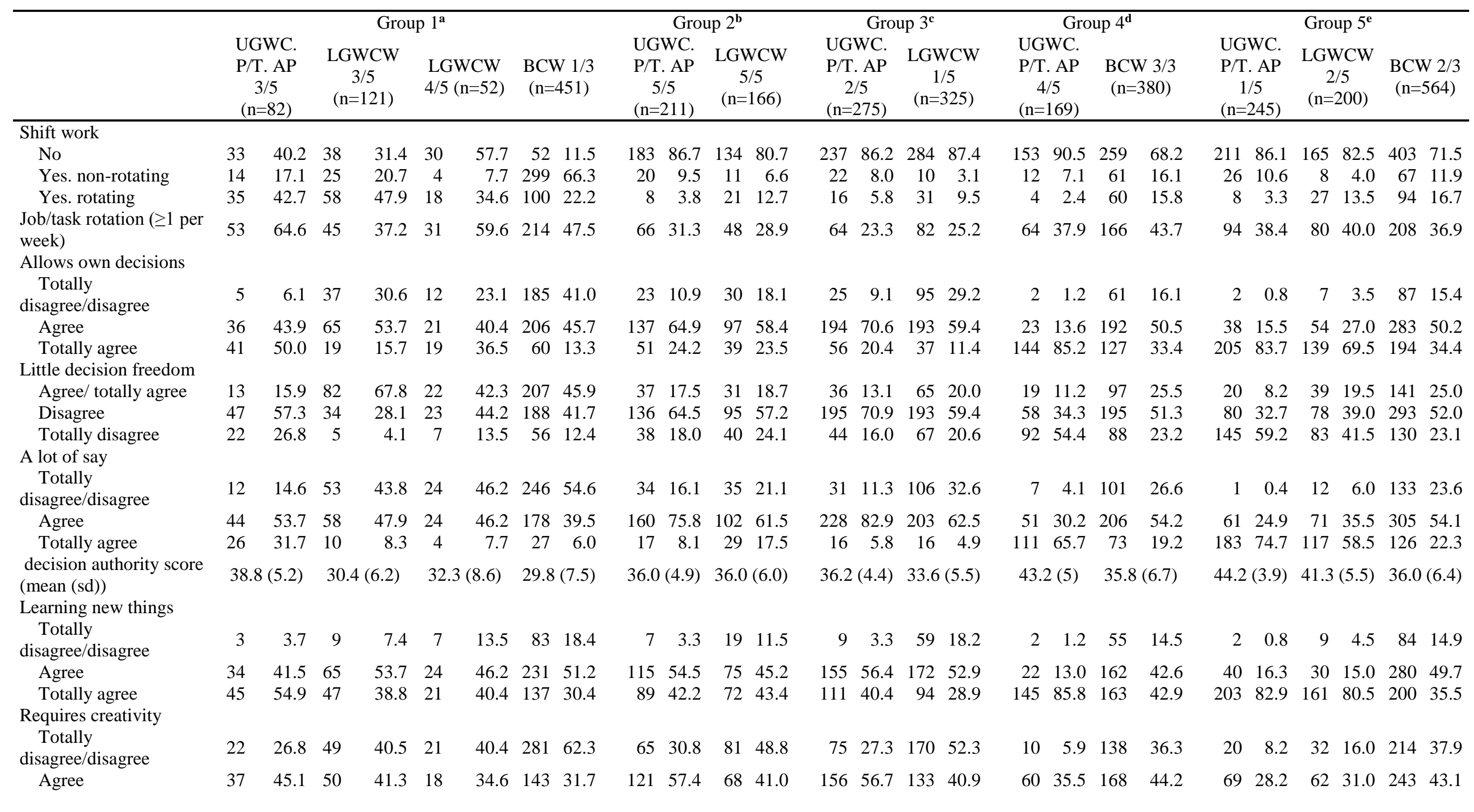


Totally agree

High skill level

Totally

disagree/disagree

Agree

Totally agree

Develop own abilities

Totally

disagree/disagree

Agree

Totally agree

Variety

Totally

disagree/disagree

Agree

Totally agree

Skill discretion score

(mean (sd))

Work pace dependent on

Paced work/automatic rate

Colleagues' work

Quantified targets

Permanent controls or

surveillance

Customers demand

High repetitiveness of

tasks

No

2 to 4 h/day

$\geq 4 \mathrm{~h} /$ day

$23 \quad 28.1 \quad 22$

18.213

$\begin{array}{lll}25.0 & 27 \quad 6.0\end{array}$

$\begin{array}{lllll}15 & 18.3 & 18 & 14.9 & 5\end{array}$

$\begin{array}{lll}10 & 12.2 \quad 35\end{array}$

$28.9 \quad 19$

$\begin{array}{lllll}45 & 54.9 & 63 & 52.1 & 23\end{array}$

$\begin{array}{lllll}27 & 32.9 & 23 & 19.0 & 10\end{array}$

$6 \quad 7.3 \quad 40$

33.111

$\begin{array}{lllll}46 & 56.1 & 61 & 50.4 & 27\end{array}$

$30 \quad 36.6 \quad 20$

$\begin{array}{ll}50.4 & 27 \\ 16.5 & 14\end{array}$

$35.5(5.6)$

6) $31.4(5.9)$

$\begin{array}{lll}38.5 & 140 & 31.0\end{array}$

$\begin{array}{lll}9.6 & 29 & 6.4\end{array}$

$\begin{array}{lll}44.2 & 216 & 47.9\end{array}$

$\begin{array}{lll}19.2 & 39 & 8.7\end{array}$ $\begin{array}{lllll}21 & 25.6 & 60 & 49.6 & 27\end{array}$

$\begin{array}{lllll}46 & 56.1 & 43 & 35.5 & 20\end{array}$

$\begin{array}{lllllllllll}51.9 & 282 & 62.5 & 37 & 17.5 & 69 & 41.6 & 71 & 25.8 & 200 & 61.5\end{array}$

$36.5196 \quad 43.5$

$21.2 \quad 184 \quad 40.8$

$\begin{array}{lll}51.9 & 213 & 47.2\end{array}$

$26.9 \quad 54 \quad 12.0$

$30.7(7.0) \quad 27.8(6.3)$

$\begin{array}{lllll}45 & 54.9 & 0 & 0.0 & 49\end{array}$

$\begin{array}{lllll}47 & 57.3 & 38 & 31.4 & 19\end{array}$

$\begin{array}{lllll}60 & 73.2 & 49 & 40.5 & 30\end{array}$

$94.2 \quad 305 \quad 67.6$

$\begin{array}{lll}36.5 & 237 & 52.6\end{array}$

$\begin{array}{lll}57.7 & 364 & 80.7\end{array}$

$\begin{array}{lllll}68 & 82.9 & 98 & 81.0 & 19\end{array}$

$\begin{array}{lllll}55 & 67.1 & 60 & 49.6 & 27\end{array}$ $\begin{array}{lll}36.5 & 214 & 47.5\end{array}$

$\begin{array}{lll}51.9 & 31 & 6.9\end{array}$ $\begin{array}{llll}152 & 72.0 & 84 & 50.6\end{array}$

$\begin{array}{llll}22 & 10.4 & 13 & 7.8\end{array}$

$\begin{array}{llll}30 & 14.2 & 37 & 22.3\end{array}$

$\begin{array}{llll}17 & 8.1 & 26 & 15.7\end{array}$

$\begin{array}{llll}31 & 14.7 & 23 & 13.9\end{array}$

$\begin{array}{llll}158 & 74.9 & 100 & 60.2\end{array}$ $\begin{array}{llll}22 & 10.4 & 43 & 25.9\end{array}$

34.6 (3.9) $32.7(5.5)$

$\begin{array}{llll}1 & 0.5 & 2 & 1.2\end{array}$

$\begin{array}{llll}135 & 64.0 & 115 & 69.3\end{array}$

$\begin{array}{llll}168 & 79.6 & 132 & 79.5\end{array}$

$\begin{array}{llll}43 & 20.4 & 34 & 20.5\end{array}$

$\begin{array}{llll}187 & 88.6 & 151 & 91.0\end{array}$ $\begin{array}{llll}164 & 77.7 & 103 & 62.1\end{array}$ $\begin{array}{llll}188 & 68.4 & 124 & 38.2\end{array}$

$\begin{array}{llll}16 & 5.8 & 1 & 0.3\end{array}$

$\begin{array}{llll}31 & 11.3 & 108 & 33.2\end{array}$

$\begin{array}{llll}225 & 81.8 & 208 & 64.0\end{array}$

$\begin{array}{llll}19 & 6.9 & 9 & 2.8\end{array}$

$\begin{array}{llll}39 & 14.2 & 70 & 21.5\end{array}$

$\begin{array}{llll}199 & 72.4 & 227 & 69.9\end{array}$ $\begin{array}{llll}37 & 13.5 & 28 & 8.6\end{array}$

34.8 (4.1) 30.2 (5.2)

$\begin{array}{llll}0 & 0.0 & 2 & 0.6\end{array}$

$\begin{array}{llll}37 & 13.5 & 28 & 8.6\end{array}$

$\begin{array}{llll}35 & 12.7 & 16 & 4.9\end{array}$

$\begin{array}{llll}93 & 33.8 & 103 & 31.7\end{array}$ $\begin{array}{llll}21 & 7.6 & 16 & 4.9\end{array}$ $\begin{array}{llll}99 & 58.6 & 74 & 19.5\end{array}$

$\begin{array}{llll}5 & 3.0 & 128 & 33.7\end{array}$

$\begin{array}{llll}78 & 46.2 & 171 & 45.0\end{array}$

$\begin{array}{llll}86 & 50.9 & 81 & 21.3\end{array}$

$\begin{array}{llll}4 & 2.4 & 201 & 52.9\end{array}$

$\begin{array}{llll}43 & 25.4 & 76 & 20.0\end{array}$ $\begin{array}{llll}122 & 72.2 & 103 & 27.1\end{array}$

$\begin{array}{llll}5 & 3.0 & 63 & 16.6\end{array}$

$\begin{array}{llll}50 & 29.6 & 212 & 55.8\end{array}$ $\begin{array}{llll}114 & 67.5 & 105 & 27.6\end{array}$

41.5 (3.7) $33.8(6.0)$

$\begin{array}{llll}0 & 0.0 & 74 & 19.5\end{array}$

$\begin{array}{lllll}105 & 62.1 & 136 & 35.8\end{array}$

$\begin{array}{llll}138 & 81.7 & 263 & 69.2\end{array}$

$\begin{array}{llll}43 & 25.4 & 142 & 37.4\end{array}$

$\begin{array}{llll}153 & 90.5 & 380 & 100.0\end{array}$ $\begin{array}{llllll}156 & 63.7 & 106 & 53.0 & 107 & 19.0\end{array}$

$\begin{array}{llllll}12 & 4.9 & 31 & 15.5 & 194 & 34.4\end{array}$ $\begin{array}{llllll}113 & 46.1 & 120 & 60.0 & 269 & 47.7\end{array}$ $\begin{array}{llllll}120 & 49.0 & 49 & 24.5 & 101 & 17.9\end{array}$

$\begin{array}{llllll}1 & 0.4 & 3 & 1.5 & 309 & 54.8\end{array}$ $\begin{array}{llllll}51 & 20.8 & 71 & 35.5 & 121 & 21.5\end{array}$ $\begin{array}{llllll}193 & 78.8 & 126 & 63.0 & 134 & 23.8\end{array}$

$\begin{array}{llllll}2 & 0.8 & 3 & 1.5 & 93 & 16.5\end{array}$ $\begin{array}{llllll}53 & 21.6 & 63 & 31.5 & 310 & 55.0\end{array}$ $\begin{array}{llllll}190 & 77.6 & 134 & 67.0 & 161 & 28.6\end{array}$ 41.8 (3.1) $38.7(3.5) \quad 33.1(6.3)$

$\begin{array}{llllll}1 & 0.4 & 2 & 1.0 & 28 & 5.0\end{array}$ $\begin{array}{llllll}15 & 6.1 & 20 & 10.0 & 121 & 21.5\end{array}$ $\begin{array}{llllll}21 & 8.6 & 33 & 16.5 & 239 & 42.4\end{array}$ $\begin{array}{llllll}23 & 9.4 & 27 & 13.5 & 87 & 15.4\end{array}$ $\begin{array}{lllllll}103 & 42.0 & 107 & 53.5 & 0 & 0.0\end{array}$

${ }^{a}$ Group 1: Low decision latitude with pace constraints.

${ }^{\mathrm{b}}$ Group 2: Medium decision latitude with pace constraints.

${ }^{c}$ Group 3: Low decision latitude with low pace constraints.

${ }^{\mathrm{d}}$ Group 4: High decision latitude with pace constraints.

${ }^{\mathrm{e}}$ Group 5: High decision latitude with low pace constraints.

UGWC. P/T. AP: upper-grade white-collar workers and professionals and technicians. associate professionals

LGWCW: lower-grade white-collar workers

$\mathrm{BCW}$ : blue-collar workers 